\title{
Down Regulation of Plant Pathogenic Fungus Fusarium Oxysporum by Tree Extracts
}

\author{
Rupnarayan Sett* \\ Division of Genetics and Plant Propagation, Tropical Forest Research Institute, India
}

Submission: July 13, 2017, Published: September 12, 2017

*Corresponding author: Rupnarayan Sett, Division of Genetics and Plant Propagation, Tropical Forest Research Institute, Jabalpur, Madhya

Pradesh, India, Email: ruppuran2001@yahoo.co.in

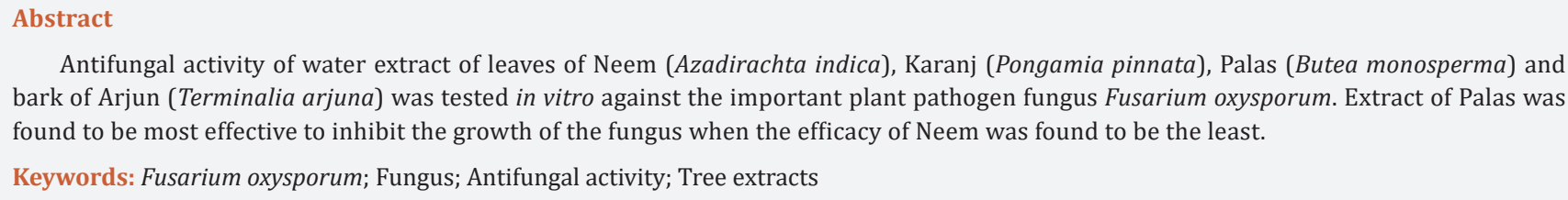

Antifungal activity of water extract of leaves of Neem (Azadirachta indica), Karanj (Pongamia pinnata), Palas (Butea monosperma) and bark of Arjun (Terminalia arjuna) was tested in vitro against the important plant pathogen fungus Fusarium oxysporum. Extract of Palas was found to be most effective to inhibit the growth of the fungus when the efficacy of Neem was found to be the least.

Keywords: Fusarium oxysporum; Fungus; Antifungal activity; Tree extracts

\section{Introduction}

Fusarium is an important plant pathogen causing serious vascular wilt and root rot diseases of several economically important plants like Gamhar (Gmelina arborea) and Sissoo (Dalbergia sissoo) [1]. It is more prevalent in tropical countries, also abundant in cultivated soils both in temperate and tropical regions. The antifungal activity of different tree extract is an important research area to be explored [2]. It is already reported that fresh extracts of some forest plants e.g. Neem (leaf), Karanj (leaf), Palas (leaf), Arjun (bark) are used by different tribal group for treating their different skin diseases, most of which are caused by human pathogenic fungi [3]. This finding generated the background of this idea that these plant products might have probable antifungal effects (antagonist action) on plant pathogenic fungus too; freshly made plant extracts were applied in vitro against Fusarium oxysporum. The results came out with a deep promise, which warrants further investigation.

Neem (Azadirachta indica A. Juss) (Meliaceae) is a large, evergreen tree widely occurring in tropical forests of India. Chemical compound found in neem leaf are azadirachtin, nimbolide, quercetin and $\beta$-sito sterol [4]. Neem is used in Ayurvedic medicine for leprosy and skin diseases, in fever and for purification of blood. Leaves are applied as poultice to boils. Externally the leaves are applied over skin disease as an antiseptic; they are specially used for boils, chronic ulcers, eruptions of smallpox, syphilitic sores, glandular swelling, wound, etc. The leaves are recorded to have carminative, expectorant, anti-helminthic, antidotal, diuretic and insecticide actions. The fresh juice with salt is applied for killing intestinal worms; with honey, the juice is prescribed for jaundice and skin disease. It is a grand remedy in chronic fever, glowing heat and burning especially in face, eyes, and palms of hand and soles of feet in open air [5-7].

Palas (Butea monosperma) (Fabaceae) is a deciduous tree; by habitat, it is indigenous to the forest of Ceylon, Burma, central and west Nepal, and common throughout in India. In the chemical composition of Palas leaves are found $\alpha$-amyrin, $\beta$-sito sterol, its glycoside and sucrose are found. Glycerides of palmitic, steric, linoceric, oleic and linoleic acids are found in the seed oil in addition to a nitrogenous acidic compound along with palasonin, butrin, isobutrin, coreopsin, isocoreopsin and sulphurein. Palas is efficacious in the treatment of vaginal disease, helminthic and hemorrhages. It is externally applied in piles ulcers, tumors and dropsy. Leaf-juice is used as astringent, tonic diuretic and aphrodisiac and is applied to cure boils, pimples, tumors and hemorrhages. Juice of leaves mixed with curd is beneficial in heat eruption in children $[8,9]$.

Arjun (Terminalia arjuna) (Combretaceae) is a large evergreen tree with whitish bark. By habitat it is found common on the bank of rivers, streams and dry watercourses in moist deciduous forests throughout India. In the chemical composition of arjun bark are found arjunolic acid, tomentosic acid, $\beta$-sito sterol, ellagic acid, saponin and leucodelphinidin. Bark contains a crystalline compound arjurine (a lactone), 
arjunetin, essential oil tanin pyrocatechol and large quantities of calcium salt and traces of $\mathrm{Al}$ and $\mathrm{Mg}$ salts, reducing sugar and coloring matter. The extract of the bark of Arjun is a cardiac tonic, diuretic, expectorant, febrifuge haemostatic and useful in bilious infections, blood dysentery, blood pressure, fever, fractures of bone, heart disease, inflammatory conditions, leucorrhoea and sores and is an antidote to poisons. The decoction is used as a wash in ulcers and cancer; ash of the bark is prescribed to heal up scorpion bite $[10,11]$.

Karanj (Pongamia pinnata) (Fabaceae) is a medium sized glabrous tree. By habitat it is native to Western-Ghat and is found all over India on the bank of rivers and stream. In action it is an alternative antiseptic, astringent, carminative, cooling, demulcent, parasiticide and stimulant. It is effective in the treatment of abdominal enlargements, diabetes, diarrhea dyspepsia, epilepsy, flatulency, insanity, leprosy, skin disease, scabies, and herpes and other cutaneous diseases, ulcers, fistulous sores, bleeding piles and whooping cough. Karanj extract is an effective remedy for all skin diseases such as eczema, scabies, leprosy and ulcers. Root and bark are bitter hot, acrid, anti-helminthic and useful in diseases of eye, vagina, skin, tumors, piles, wounds, ulcers, urinary discharges, itching and enlargement of spleen. Juice of roots used for closing fistulous sores and cleaning foul ulcers, given internally with equal quantities of coconut milk and limewater for gonorrhea. Leaves in forms of poultice applied to ulcers infected with worms [12].

The genus Fusarium is an important plant pathogen causing wilt and root rot disease of several economically important plants $[13,14]$. It is more prevalent in tropical countries. The genus Fusarium contains approximately 50 species [15], which are widely distributed in soil and have been isolated from permafrost of arctic to the sand of the Sahara. They are abundant in cultivated soils both in temperate and tropical regions $[16,17]$. Some of the species are serious plant pathogens and are responsible for causing vascular wilts and root rots. The hyphae are hyaline, branched and septate. Conidia are formed in slimy effuse sporodochia called pionnotes, or sometimes scattered on the mycelium. Condiophores are quite short, simple or branched, septate bearing a terminal phialide. The phialides are subulate i.e. widest at the base, narrowing to a point like an all. The conidia, which are slimy, are of two types: microconidia (single celled, oval or comma shaped pyriform or elongate) and macroconidia (which are hyaline or pale spindle shaped with pointed end hence the name fucus meaning spindle). The three or more septa with a distinct "foot cell" is the most distinct feature of Fusarium. Chlamydospores if present are formed on the hyphae or on the microconidia. Microconidia may be present or lacking; the conidia are formed in succession and become enveloped in a slimy mass. In addition to conidia and chlamydospores some species forms sclerotia, which are brightly colored [18-20].
Fusarium oxysporum species is a vascular wilt pathogen; these are distinguished by host specificity and designated as form an especial is in a trinomial nomenclature.

\section{Materials and Methods}

\section{Preparation of plant extracts}

$100 \mathrm{~g}$ plant parts crushed in $100 \mathrm{ml}$ water and the paste so obtained was dissolved in $500 \mathrm{ml}$ distilled water filtered through Whatman filter paper no.1. The residue was thoroughly washed and the volume was $1000 \mathrm{ml}$. This was the main extract stock solution (100\%), and this was diluted further to $50 \%$. Matured green leaves of Azadirachta indica (Neem), Pongamia pinnata (Karanj), Butea monosperma (Palas) and bark of Terminalia arjuna (Arjun) were collected from the forest and used fresh. Each plant part was weighed $100 \mathrm{~g}$, and was washed in fresh water thoroughly and lastly in sterile distilled water. The leaves of each species of Neem, Karanj and Palas were crushed and made to fine paste in sterile distilled water; the volume was made up to $100 \mathrm{ml}$. Similarly the bark of Terminalia arjuna plant was also grinded and then made to a fine paste in sterilized water as stated before. Then, the paste of leaves of selected plant species was filtered by using No.1 "Whatman" filter paper and the extracts were obtained separately. The same process was repeated in the case of bark paste of Terminalia arjuna.

\section{Dosage preparation}

Considering the strength of the filtered extract as $100 \%$, a $50 \%$ dose was also made with sterile distilled water for each sample. Sterile distilled water was used for the 'control' experiment petri-plates, and $0.2 \%$ bavistin (a common and very effective antifungal agent) solution for the 'standard' experiments. $1 \mathrm{ml}$ of extract of each application material was poured in petri-plates.

\section{Preparation of petri-plates}

The standard potato dextrose agar medium was used throughout the investigation. $10 \mathrm{ml}$ of the medium was poured in each of $90 \mathrm{~mm}$ petri-plates in sterile condition in laminar airflow, and was allowed to settle up to cooling to solidify. $1 \mathrm{ml}$ each of $50 \%$ and $100 \%$ extract solutions as well as the control distilled water and standard $0.2 \%$ bavistin solutions were poured in petri-plates containing PDA medium. Then to each plate a $0.1-0.2 \mathrm{~mm}$ inoculum of Fusarium oxysporum was subcultured and then kept in BOD incubator at $28-30{ }^{\circ} \mathrm{C}$ for $48 \mathrm{~h}$.

\section{Results and Discussion}

Bioassay tests with fresh extracts of the trees viz. Neem, Palas, Karanj and Arjun were conducted on cultures of Fusarium oxysporum in petri-plates containing PDA medium along with other treatments (control: sterile distilled water; standard: $0.2 \%$ bavistin). The cultures were allowed to grow and get incubated in the BOD incubator. The observations were noted down at 48, 72 and 96 hours (Table 1). 


\section{Recent Advances in Petrochemical Science}

Table 1: Growth of Fusarium oxysporum after treatment at different hours of treatment and data presented in mean \pm s.d. of five replicates.

\begin{tabular}{|c|c|c|c|}
\hline \multirow{2}{*}{ Applications } & \multicolumn{3}{|c|}{ Growth of Fusarium oxysporum (Colony diameter in mm) } \\
\cline { 2 - 4 } & $\mathbf{4 8 \text { hours }}$ & $\mathbf{7 2}$ hours & $\mathbf{9 6}$ hours \\
\hline Distilled water & $2.16 \pm 0.20$ & $3.56 \pm 0.24$ & $5.56 \pm 0.28$ \\
\hline $0.2 \%$ Bavistin & $0.00 \pm 0.00$ & $0.00 \pm 0.00$ & $0.00 \pm 0.00$ \\
\hline Neem 50\% & $2.04 \pm 0.22$ & $3.44 \pm 0.22$ & $5.26 \pm 0.16$ \\
\hline Neem 100\% & $1.88 \pm 0.18$ & $3.32 \pm 0.26$ & $4.80 \pm 0.20$ \\
\hline Palas 50\% & $1.08 \pm 0.14$ & $1.32 \pm 0.10$ & $1.54 \pm 0.22$ \\
\hline Palas 100\% & $0.60 \pm 0.18$ & $0.72 \pm 0.18$ & $0.78 \pm 0.12$ \\
\hline Karanj 50\% & $1.00 \pm 0.26$ & $1.24 \pm 0.22$ & $1.34 \pm 0.16$ \\
\hline Karanj 100\% & $1.08 \pm 0.20$ & $1.16 \pm 0.24$ & $1.30 \pm 0.20$ \\
\hline Arjun 50\% & $1.64 \pm 0.22$ & $1.80 \pm 0.28$ & $1.94 \pm 0.18$ \\
\hline Arjun 100\% & $1.26 \pm 0.16$ & $1.42 \pm 0.22$ & $1.60 \pm 0.20$ \\
\hline
\end{tabular}

Wilting in plants occurs due to several types of pathogens of which Fusaria are the most common [21]. Often the first indication of wilting is that the lower leaf petioles bend downwards so that the angle between them and the main stem becomes obtuse, sometimes slight vein clearing occurs followed by the yellowing of the lower leaves. Vascular browning and the development of tylosa and gums have been observed. Ultimately the plant wilts, shrivels and dies [22]. The fungus present in the soil invades the root cortex usually without damaging it to any great extent and then becomes established in the vessels. Later when the host plant is dying it grows out into the cortical tissues and then it may spread to adjacent healthy plants through root contact. The wilting may be associated with increased levels of indole-acetic-acid, production of ethylene and enzyme activity. However, plugging of the vessels and production of toxin by the fungus are the two principal causes of wilting [23]. One of the practical ways of controlling these wilt diseases in the field is by planting resistance varieties which may produce root exudates acting on the fungal spores containing inhibitory substances which reduce the toxin or enzyme production by the pathogen and also have such histological changes which limit the spread of the fungus. Some measures like adding fungicides in the soils before planting and rotation of the crops may also be helpful but less practical.

Antifungal activity of leaf extracts of Neem was evaluated against Curvularia lunata; it was found that the radical growth, sporulation and spore germination of the test fungus was inhibited [24]. 14 fungi were tested causing human mycoses with various extracts from neem leaves, neem oil and seed kernels and found that some of the extracts in an eluotropic solvent series were effective and reduced the growth of the mycelium of dermatophytes. Low polarity extracts were better than those of high polarity. The petrol ether leaf extracts was possibly one of the reasons for the growth inhibiting effects [25]. Neem has been reported to be effective against certain human fungi, which are even difficult to control, by modern synthetic fungicides. Some of them are: Trichophytonan 'athlete's foot" fungus that infect hair, skin and nails; Epidermophyton-a 'ringworm' that invades both skin and nails of the feet; Microsporum-a 'ringworm' that invades hair skin and rarely nails; Tricosporon-a fungus of the intestinal tract; Geotricum-a yeast like fungus that causes infection of the bronchi, lung and mucous membranes; Candida - a yeast like fungus that is part of the normal mucous flora but can get out of control, leading do lesions in mouth, vagina, skin, hands and lungs. The extract of neem totally inhibits the protease activity of Trichophyton, which could be attributed to the high phenol content of the plant. The steam distillate of leaves yielding oil containing a number of tri- and tetra-sulphides shows promising antifungal activity in vitro against Trichophyton mentagrophytes. Nimbidin inhibits the growth of Tinea rubrum though neem oil fails to show any appreciable antifungal activity against Candida albicans. Extracts of various parts of the plant also possess antifungal activity against a wide range of plant fungi including complete stoppage of production of aflatoxin by Aspergillus flavus. Neem is known to have medicinal and insect repellant activity due to the presence of alkaloid [26,27] studied the fungicidal effect of neem on some soil-born pathogen of Chickpea (Cicer arietinum). [28] reported the growth of the test fungi viz. Fusarium oxysporum f. sp. ciceri, Rhizoctonia solani, Sclerotium rolfsii and Sclerotium sclerotium was inhibited in liquid medium containing extracts of leaf, trunk, bark, fruit and pulp from Neem.

The control of fungal diseases in trees is an area of indepth research and integrated approaches $[29,30]$. In our experiments, neem extract did not show much effect on inhibiting the growth of Fusarium oxysporum. One of the causes may be that all the extracts were made in distilled water, and not in organic solvent, which allows leaching of 
the oil portion in the extract to get out in active form. But very interestingly, water extracts of Palas leaves (Butea monosperma) was very effective in inhibiting the growth; too some extent that of Karanj (Pongamia pinnata) too. It should be reminded that Karanj leaves also contain oil. Water extract of Arjun (Terminalia arjuna) also remarkably inhibited the growth. In the positive control, $0.2 \%$ Bavistin very effectively and completely inhibited the grow th of Fusarium oxysporum, as this is a known very strong chemical fungicide. These results indicate that at least the water-soluble ingredients present in the leaves of Palas and Karanj, and in the bark of Arjun, contain active ingredients, which may effectively control the growth of Fusarium oxysporum at least in the initial stage of fungal infection when applied fresh. This finding can be investigated further to reach concrete conclusions and on the possible use of the plant extracts against the dreaded plant pathogen in agriculture and forestry.

\section{References}

1. Bakshi BK (1954) Wilt disease of Shisham (Dalbergia sissoo Roxb.) due to Fusarium solani infection. Nature 117: 278.

2. Gomathi V, Kannabiran B (2000) Inhibitory effects of leaf extract of some plants on the anthracnose fungi infecting Capsicum annum. Indian Phytopath 53: 305-308.

3. Sekhawat PS, Prasada R (1971) Antifungal properties of some plant extracts. I. Inhibition of spore germination. Indian Phytopath 24: 800802.

4. Chaurasia SC, Jain PC (1978) Antifungal activity of essential oil of four medicinal plants. Melia azadirachta. Indian J Med Res 40: 511.

5. Dastur JF (1985) Medicinal plant of India and Pakistan, Azadirachta indica ADR Juss. D.B. Taraporevala Sons and Co. Pvt. Ltd, Bombay, India, pp. 29-30.

6. Randhawa NS, Parmar BS (1996) Neem, anti-infective activity (a) antifungal activity. New Age International Pvt. Ltd, India, p. 292.

7. Joshi SG (2000) Medicinal plant, Azadiracta indica A. Juss. Oxford Publ, New Delhi, India, pp. 261-262.

8. Dastur JF (1985) Medicinal plant of India and Pakistan, Butea monosperma Kuntz. D.B. Taraporevala Sons and Co. Pvt. Ltd, Bombay, India, pp. 39-40.

9. Joshi SG (2000) Medicinal plant, Butea monosperma Linn. Merr. Oxford Publ, New Delhi, India, pp. 205-206.

10. Dastur JF (1985) Medicinal plant of India and Pakistan, Terminalia arjuna W and A. D.B. Taraporevala Sons and Co. Pvt. Ltd, Bombay, India, p. 162.

11. Joshi SG (2000) Medicinal plant, Terminalia arjuna W and A. Oxford Publ, New Delhi, India, pp. 192-193.

12. Dastur JF (1985) Medicinal plant of India and Pakistan, Pongamia pinnata Pier. D.B. Taraporevala Sons and Co. Pvt. Ltd, Bombay, India, pp. 39-40.
13. Mehrotra BS, Aneja KR (1990) An introduction to Mycology, Order Tuberculariales, Genus Fusarium, Wiley Eastern Ltd, New Delhi, India, pp. 603-610.

14. Harsh NSK, Dadwal VS, Jamaluddin (1992) A new post emergence dumping of disease of Eucalyptus seedling. Indian Forester 118: 279283.

15. Booth C (1971) The genus Fusarium. Commonwealth Mycological Institute, Kew, Surrey, England, pp. 237-238.

16. Bakshi BK (1957) Wilt disease of Shisham (Dalbergia sissoo Roxb.). The effect of soil moisture on the growth and survival of Fusarium solani in the laboratory. Indian Forester 83: 505-511.

17. Bakshi BK, Arora AK, Singh S (1957) Root diseases of Shisham (Dalbergia sissoo Roxb.) V. Incidence of disease in relation to soil $\mathrm{pH}$ and soil texture. Indian Forester 83: 555-558.

18. Bakshi BK, Singh S (1954) Wilt disease of Shisham (Dalbergia sissoo Roxb.). I. Introduction and host parasite relationship. Indian Forester 80: 316-322.

19. Bakshi BK (1955) Wilt disease of Shisham (Dalbergia sissoo Roxb.) Behavior of Fusarium solani, the wilt pathogen in soil. Indian Forester 81: 276-278.

20. Bakshi BK (1976) Forest pathology: Principal and practices in forestry. Govt. of India Publication. New Delhi, India.

21. Dube HC (1983) An Introduction to Fungi, Genus Fusarium. Vikas Publ. House Pvt. Ltd. New Delhi, India, pp. 415-418.

22. Dadwal VS, Jamaluddin (2002) A note on sheath blight of Dendrocalamus asper and its control. Indian Forester 128: 470-472.

23. Dadwal VS, Jamaluddin (2003) Biocontrol of important pathogens of forestry species by Streptomyces formulation. Indian Forester 129: 1270-1279.

24. Bhowmick BN, Vardhan V (1981) Antifungal activity of some leaf extracts of medicinal plant on Curvularia lunata. Indian Phytopath 34: 385-386.

25. Ketkar CM (1976) Utilization of neem (Azadirachta indica A. Juss.) and its by-products. Khadi and Village Industries Commission, Bombay, India.

26. Mariappan V (1995) Antifungal activity of neem (Azadirachta indica) leaves against some phyto-pathogenic fungi. Neem for the management of crop disease. Dutta SK (ed.), Associated Publishing Co, New Delhi, India, pp. 49-50.

27. Singh UP, Singh HB, Singh RB (1980) The fungicidal effect of Neem extracts on some soil-borne pathogens of gram (Cicer arietinium). Mycologia 72: 1077-1093.

28. Randhawa NS, Parmar BS (1993) Neem Research and Development: Bioactivity against plant pathogen. Society of Pesticide Science, New Delhi, India, pp. 44-148.

29. Mehrotra BS (1992) The Fungi: An introduction, form Genus Fusarium Link. Today and Tomorrows Printers and Publishers, New Delhi, India, pp. 421-422.

30. Singh Y, Verma RK, Jamaluddin (2002) An integrated approach to control Fusarium wilt of Dalbergia sissoo. Indian Forester 128(4): 432438. 


\section{Recent Advances in Petrochemical Science}

CDis work is licensed under Creative CC) (i) Commons Attribution 4.0 Licens

DOI: 10.19080/RAPSCI.2017.02.555599
Your next submission with Juniper Publishers will reach you the below assets

- Quality Editorial service

- Swift Peer Review

- Reprints availability

- E-prints Service

- Manuscript Podcast for convenient understanding

- Global attainment for your research

- Manuscript accessibility in different formats

( Pdf, E-pub, Full Text, Audio)

- Unceasing customer service

Track the below URL for one-step submission https://juniperpublishers.com/online-submission.php 